Dossier Anthropology on Latin America and the Caribbean today:

New Theoretical and Methodological Challenges

\title{
Populism, inequality, and the construction of the "other": an anthropological approach to the far right in Brazil
}

\section{Rebecca Lemos Igreja}

'Universidade de Brasília, Departamento de Estudos Latino-Americanos, Programa de Pós-Graduação da Faculdade de Direito, Brasília/DF, Brasil

\begin{abstract}
Starting from the discussion about the contributions of anthropological perspectives to the study of the extreme right, the article proposes to present some initial analysis about this political ideology in Brazil. It focuses on the construction of the sociocultural and ideological profile of the Bolsonaro government. Specifically, the goal is analysing the form in which the Brazilian government redefines and considers ethnic-racial identities and how it builds its own identity by opposing them. In this sense, this article addresses indigenous alterity, seeking to observe how it is re-signified in Bolsonaro's project. Observing this encounter between the far-right and otherness in the Brazilian context allows to verify values and meanings it gives to cultural plurality, the imaginaries and social representations it builds, and from this to understand how it presents itself and which project of society it defends.
\end{abstract}

Keywords: Far-right; radicalism; extremism; Bolsonaro; indigenous alterity; anthropology of extreme-right. 


\section{Populismo, desigualdad y construcción del "otro": una aproximación antropológica a la extrema derecha en Brasil}

\section{Resumen}

Desde la discusión sobre los aportes de las perspectivas antropológicas al estudio de la extrema derecha, el artículo propone presentar un análisis inicial sobre esta ideología política en Brasil. Se enfoca en la construcción del perfil sociocultural e ideológico del gobierno de Bolsonaro. Específicamente, el objetivo es analizar la forma en que el gobierno brasileño redefine y considera las identidades étnico-raciales y cómo construye su propia identidad al oponerse a ellas. En este sentido, este artículo aborda la alteridad indígena, buscando observar cómo es resignificada en el proyecto de Bolsonaro. Observar este encuentro entre la extrema derecha y la alteridad en el contexto brasileño permite verificar los valores y significados que le da a la pluralidad cultural, los imaginarios y representaciones sociales que construye, y a partir de ello comprender cómo se presenta y qué proyecto de sociedad defiende.

Palabras-clave: extrema-derecha; radicalismo; extremismo; Bolsonaro; alteridad indígena; antropología de extrema-derecha.

\section{Populismo, desigualdade e construção do "outro": uma abordagem antropológica da extrema-direita no Brasil}

\section{Resumo}

Partindo da discussão sobre as contribuições das perspectivas antropológicas para o estudo da extrema-direita, o artigo se propõe a apresentar algumas análises iniciais sobre essa ideologia política no Brasil. Tem como foco a construção do perfil sociocultural e ideológico do governo Bolsonaro. Especificamente, o objetivo é analisar a forma como o governo brasileiro redefine e considera as identidades étnico-raciais e como constrói sua própria identidade opondo-se a elas. Nesse sentido, este artigo aborda a alteridade indígena, buscando observar como ela é ressignificada no projeto de Bolsonaro. Observar esse encontro entre extrema-direita e alteridade no contexto brasileiro permite verificar valores e significados que ela atribui à pluralidade cultural, aos imaginários e representações sociais que constrói, e a partir disso compreender como se apresenta e qual projeto de sociedade defende.

Palavras-chave: Extrema-direita; radicalismo; extremismo; Bolsonaro; alteridade indígena; antropologia de extrema direita. 


\title{
Populism, inequality, and the construction of the "other": an anthropological approach to the far right in Brazil
}

\author{
Rebecca Lemos Igreja
}

The representatives of the far right that have come to power throughout the world have grabbed the attention of social scientists, who have pondered the phenomenon and its consequences. Many of their studies focus on what analysts identify as 'neofascism', 'neopopulism', and/or 'neoconservatism'. A range of anthropological perspectives have contributed to the ensuing debates through analyses of groups of supporters, religious radicalism, and the impact of the rise of the far right on local populations, particularly on minorities who have suffered the consequences of the policies and hate speech promoted by agents of this political persuasion. Many of these studies take digital social networks as the privileged loci for the expression of extremist ideas and as media for spreading so-called 'fake news'. Research carried out in the digital world has, in turn, set a methodological challenge to the contemporary social sciences.

Indeed, it has been largely through the use of extensive digital social networks that this new radical right has promoted a hate speech that rejects the 'other, and/or elaborates a particular conception of that 'other', particularly of those who are associated with specific groups, including immigrants, Blacks, LGBTQIA+, and other political minorities. This speech is part of an ideological project that naturalizes inequality and exclusion by recourse to traditional, religious and identarian values deemed superior to all others (Igreja and Negri, 2020).

Studies that focus on social networks and the fake news that they disseminate, however, tend to obscure other mediums for the expansion and consolidation of the far-right ideas which are surreptitiously settling into everyday affairs, making use of principles propagated by elites and conservative intellectuals and championed by religious, traditionalist and nationalist groups that self-proclaim their protagonism in defining the proper values of a people or nation. These ideas have been gaining ground among the diverse social groups, conferring moral authority upon them, even when the immediate interests of those who uphold them are thereby harmed. It is in the everyday functioning of state institutions, in the elaboration of public policies, and in proposals for legislation that this ideological project becomes concrete. It is consolidated through a form of government that establishes itself broadly at the level of the state, altering bureaucratic structures, redefining public institutions and their aims, and reviewing the rights of citizens and the rights of citizens and national legal systems. These silent and quotidian means through which the far right operates account for the widespread support they have found in society.

In a context of deep criticism of the social sciences, delegitimized by the rise of conservative political policies, I believe that it is vital to not only reflect on the reasons for and consequences of the prominence of the far right, but also to debate how anthropology and its conceptual tools can contribute to research on this theme. My aim in this article is to proceed with reflections that began in 2020, as part of wider interdisciplinary research my team and I are developing on the current government of President Jair Bolsonaro in Brazil. 
The research project "Inequalities and the Construction of the Other by the Far Right in Brazil" contributes to recent studies of the far right, seeking to understand what facilitated its rise worldwide, tracking the ideological profile of the political parties and their representatives, as well as the socio-cultural profile of their supporters ${ }^{2}$. The project looks to understand the bases of this thought, and to explore how it penetrates into the core of society.

The members of this project have privileged research on the socio-cultural and ideological profile of this far right, analysing, in particular, how the Bolsonaro government considers and redefines ethno-racial identities, thereby constructing its own identity against them. By observing the far right's encounter and engagement with alterity in Brazil, we can establish the values, meanings, and senses that it confers upon cultural plurality, as well as the social representations and imaginaries that it constructs for the latter, coming thus to understand how it presents itself and what image of society it upholds.

Since the article discusses a research project that is still in its initial stages, I begin by reviewing the main contributions of recent anthropological perspectives on the far right. I then foreground the debate on multiculturalism and its relationship to the rise of the far right throughout the world, particularly in Latin America. Finally, I offer a preliminary analysis of research on the far right in Brazil, focusing on the issue of Brazilian Indigenous identity.

It is a fact that the government has maintained a steadily consistent attitude toward all minorities. Nonetheless, Indigenous people add a further element to government concerns, related to economic interests in the development of their lands through mining and agribusiness. Government presence has been heightened in Indigenous lands, particularly in Amazonia, accompanied by their aggressive illegal invasion. It is within this context that Bolsonaro constructs his rhetoric of Indigenous identity, redefining it according to the interests of his government and its supporters.

\section{Anthropology and the new far right}

"Anthropologists Are Talking About the New Right in Europe" (2003) is a provocative article, published in Ethnos:Journal of Anthropology, which establishes a dialogue between four anthropologists - Jonathan Friedman, Andre Gingrich, Sarah Green, and Thomas Hylland Eriksen - regarding the contributions of anthropology to an understanding of the growth of the far right in Europes. How are we to understand this phenomenon? What is new about it? What can anthropology do to challenge it? These were the questions that guided the informal conversation between the four anthropologists. Opinions, in many cases, differed, but all agreed that anthropology needs to address and analyse the issue.

Indeed, when the conversation between these anthropologists was published, the radical and populist proposals of the far right in Europe had already caused alarm among many intellectuals. Political parties, such as the Front National of France, and its main representative, Jean-Marie Le Pen, gained followers in the country

\footnotetext{
1 Research on the construction of the other by the Brazilian far right is part of wider research on the Brazilian far right supervised by Rebecca Lemos Igreja, Camilo Negri, and Talita Rampin. In this sub-project we have benefitted from the work of the graduate students Lorena Varão, Larissa Furtado, João Paulo Hakuwi Kuady Karajá, and Thayse Edith Coimbra Sampaio, and the undergraduate students Yuri Formiga dos Santos, Ricardo Daniel Lucas Monteiro de Sousa, Beatriz Amorin de Barros and Carolina Nogueira. I take the opportunity to thank them for their contributions to this article. The research is conducted by the Laboratório de Acesso à Justiça e Desigualdades (Laboratory for Access to Justice and Inequalities; LADES) and Colégio Latino-americano de Estudos Mundiais (Latin American College of Global Studies) of FLACSO/Brazil.

2 Our research is in dialogue with two international projects: IRC - Political Radicalisms, Extreme-Right, and Justice System, supported by the Law and Society Association/ Unites States of America, and supervised by Rebecca Lemos Igreja, Talita Diaz Rampin (PPGFD/UnB) and Karina Ansolabehere (UNAM/México); and DARE - Dialogue About Radicalisation and Equality, coordinated by Alexandra Poli, Bartolomeo Conti, and Nathalie Paton of the CEMS-EHESS in France.

3 This conversation took place in August of 2002 in Copenhagen, during the bi-annual meeting of the European Association of Social Anthropology. It was mediated and edited by Don Kulick (2003).
} 
by propagating a xenophobic critique of immigration, particularly from the Maghreb, alongside a staunch defence of French traditions and values. New leaders and political parties emerged and gathered momentum across the continent, in countries such as Denmark, Norway, Austria, the Netherlands, the United Kingdom, as well as in Eastern European countries. Each of these parties had their own unique proposals and profiles, but, in general, they all support an anti-immigration discourse, the defence of national cultures, and the values and traditions of a European civilization. Many of these political movements are interpreted as a return to a bygone European fascism, but more recent interpretations tend to stress that the continent is facing a new far right that garners supporters who sense that they have lost privileges, in a context of growing inequality where the appropriation and interpretation of the concept of 'culture' emerges as a priority.

A phenomenon that is common to the European and global contexts is the radicalization of a neoliberal agenda, which presupposes an end to the security networks of the state, and a sociocultural agenda that emphasises a conservative view of customs and tradition at the expense of cultural plurality and in contraposition to the multiculturalism of the last decades. As I have observed elsewhere (Igreja and Negri, 2020), extremist parties represent significant demands for social transformation, whether toward an imagined future or an idealized past (Powell, 1986). Rydgren (2007), however, cautions that older analyses of the far right which define political extremism as an anti-pluralism or a monism, such as those of Lipset and Raab, may also be usefully incorporated into current discussions. For these authors, the operational core of extremism "is the repression of difference and dissent, the closing down of the marketplace of ideas. More precisely. The operational essence of extremism, or monism, is the tendency to treat cleavage and ambivalence as illegitimate" (Lipset and Raab 1970, in Rydgren, 2007:243).

The far right's extremism and its rejection of pluralism have led a number of authors to interpret it as a sort of right-wing neopopulism. This interpretation gained traction with the election of Donald Trump as president of the United States, and later with that of Jair Bolsonaro as president of Brazil. In an effort to define the concept of neopopulism, Cas Mudde (2007) proposes that the populist has three general bases: an anti-establishment stance, authoritarianism, and nativism. Guillermo Fernández-Vázquez (2019) argues that nationalist and identarian formations in Europe were successful not only for being anti-establishment or oppositional, but also that all the parties in this political spectrum set out on the path toward a common meaning that had hitherto been denied to them. Three major events enabled this operation: the attacks on the twin towers; the 2008 economic crisis, and the refugee crisis. These events had long-lasting effects in generating mistrust of the 'other', in this case of Muslims, and in creating economic uncertainty for the future. In their goal of building a hegemonic identity, the far right thus found no difficulty in borrowing vocabularies, claims, myths, and historical references, including those that were associated with the Left and progressives.

Jan Werner Müller (2016) likewise stresses that anti-pluralism is a mark of populist thought. In his view, populists consider the elites to be immoral, corrupt and parasitic, targets against which a 'homogenous' and 'pure' people should be opposed. Their constant demand consists in affirming that they, and they alone, represent a true people. Their political distinctions are binary and framed as virtuous oppositions, either true or false, which makes populism synonymous with a morally-loaded polarization (2016:176).

Some anthropological interpretations have also analysed the far right through studies of populism, constituting what has been called an "anthropology of populism" (Hann, 2019; Mazzarella, 2019)4. These authors add weight to the idea that the concept of 'populism' has been used widely, even if often in a random manner, while seeking to reposition anthropology and to intervene in ongoing debates from the perspective of the discipline. Hann (2019) explains that, since anthropologists themselves live among subaltern populations,

4 It is also worth mentioning the volume edited by Katherine C. Donahue and Patricia R. Heck (Donahue, Heck; 2019), which discusses anthropological views on populisms and the far right, particularly in Europe and the USA. 
they come to be perceived as subversive practitioners of a populist discipline who have committed, during the $20^{\text {th }}$ Century, to an advocacy for these populations. According to Mazzarella (2019:48), we can safely say that anthropology itself - methodologically, if not ideologically - tends to assume a populist posture, typically siding with the common sense of common people, investing hope in an "unflagging popular ingeniousness". This view is backed by a common disciplinary critique of a vague and generic western liberalism which has broadened forms of exclusion and oppression in various societies.

John Comaroff (2011) highlights three important elements of populism: first, that is it is somehow a necessary condition of all anti-establishment movements, past or present, progressive of conservative; second, that on its own it is never enough to stoke the fires of politically constructive mobilizations; finally, that, in what pertains to all of these aspects, populism seems to have assumed specific and disquieting characteristics in recent years. It seems increasingly probable that populism will strengthen reductionist tendencies inherent in large swathes of contemporary politics (or anti-politics), whether religious or secular; that is, it strengthens tendencies fomented by popular identarian movements, by a renewed faith, and by a militant neoliberalism that defends the power of the market free from state regulation. According to Comaroff, global conditions have undermined loyalties between class and party in many social contexts, replacing them with other bases for identity above and below the level of the nation state; identities, in turn, which are focused on essences rather than relations, on culture instead of politics (Comaroff, 2011:107).

Although populism is a useful tool for tracing the character of various conservative and far-right leaders and governments, it is my view that, on its own, it is not enough to add depth to analyses that seek to reveal explanations for and the dynamics of how these political movements operate, and how they respond to the desires of important segments of society. 'Populism' is often used in a vague and ambiguous way, and tends to classify distinct ideas of government, both on the Left and the Right, in varied sociocultural and historical contexts, thereby obscuring their specificities and the impacts of government policies. Furthermore, it simplifies historical contexts and political conflicts that transcend the binary oppositions between the elites and the population-at-large, themselves not only socially, but also culturally, diverse. I thereby agree with Claudia Briones's (2019) Latin American-based critical review of the writings of Ernesto Laclau, an important theoretical reference for studies of populism in the region. According to Laclau (2013), populism is much more than an anomaly; on the contrary, it is the constitutive element of politics. In line with other Latin American authors, Briones believes that, by coming close to converting populism into the very form of politics, Laclau runs into a historical and evaluative lack of specificity that is accompanied by an inattention to procedure and to the complex processes of subjectification. The author's perspective does not consider the degree to which the historical context and its complexity are more than necessary to account for the construction of the people, the State, and the nation in Latin America.

I do not intend to provide an extensive review of populism and its anthropological interpretations in this article, although they constitute an important dimension of my research. Instead, I seek to reflect on the rise of the far right, offering an initial analysis of its sociocultural profile, observing its genesis, characteristics, social representations, identity, and operational dynamic. It is to this end that I engage with the anthropological literature, and in particular ethnography and the analysis and interpretation of cultures, to understand this far right in all of its complexity and plurality, as a broad cultural phenomenon. In his studies of Europe, Guillermo Fernández-Vázquez (2019:27), for instance, argues that if we are to make the peak of the far right a priority, we must take it seriously, both politically and intellectually. This means investigating what it says and what it does. How does it present itself in the public sphere? From what vantage point does it direct its discourse toward society and other political parties? How does it relate to a country's symbols? What words and signifiers does it seek to appropriate? What emotions and desires does it articulate? Fernández-Vázquez explains that these questions demand that we reflect on the far right's strategy and its programme, particularly if we start 
form the premise that society is not foolish, completely alienated, or that it suffers from a sudden loss of the capacity to discern. The use of anthropological tools for studies of the far right are tailored to addressing these issues.

Paul Stoller (2017) also notes that anthropologists are better-placed to answer how Donald Trump garnered so much support for his electoral agenda. He states: "as anthropologists well know, the deceptively simple response to these difficult questions is the central concept of our discipline, culture, which, among other things, shapes our interpretation of reality." (2017:58). For Stoller, our current epoch needs anthropology to fight Trumpism, as manifested in the loss of healthcare, growing deficits, the expansion of racial and religious intolerance, and the use of torture. One way of reconfiguring the narratives and political environment of the United States is to carry out more ethnographies:

Ethnographers spend a good amount of time with the people they seek to describe. In so doing, they develop relationships with their subjects. Over time, they develop bonds of trust with their subjects, fostering mutual respect and a deep comprehension of their culturally contoured view of the world. An ethnographer of a community of people who voted overwhelmingly for President-elect Trump would have known that there was broad, deep and enthusiastic support for Mr. Trump. They would have known not only that he understood their social and economic pain. They would have known how immersion in the ubiquitous culture of celebrity would soothe their pain. The resulting narrative proved to be a politically powerful one. We need more ethnographers and more ethnographic description so that we might better understand social and political dynamics in America and in the world (2017:59).

Agreeing with the thrust of Stoller's critique, Cristina Ohemichen (2020) brings historicity to light, explaining how the context for the empowerment of Trumpism and its views of and attacks on immigrants rely on entrenched threats and hostilities that permeate relations between the Mexico and the United States. To explain this sort of sociocultural persistence, Ohemichen proposes that we look to theories of social representation, which show how they change very slowly through time. Social representations construct imaginaries that legitimize ways of thinking, which are not exempt from oppositions characteristic of the heterogeneity of a given society. As she argues, as these imaginaries attain social legitimacy, the come to definitively contribute to the construction of relations of hegemony; in other words, the become dominant.

What remains to be addressed is how one is to carry out fieldwork in a hostile environment, made up of extremist, elitist, and racist groups. The difficulties involved in approaching these groups have led to a preference for analyses at a distance. According to Kathleen M. Blee (2007), citing Matthew Goodwin, many analyses are characterized as externalist, privileging economic, social, behavioural or cultural environments that feed organized racism and right-wing extremism, rather than on the dynamic that is proper to the far right. According to the author, although these studies have provided a crucial view of the conditions within which far-right movements flourish, they cannot completely explain their recurrent resurgence, since they are rarely a simple top-down imposition. Understanding why far-right groups emerge in specific socio-economic contexts demands, according to Blee, the analysis of individual and collective identities, how people come to see right-wing extremism as a means to exert claims based on these identities, and the processes through which far-right groups recruit members and supporters. However, as Blee also notes, such studies are hard to come by, because interviewing members of far-right groups, observing their activities, and reviewing their internal documents, are practically impossible endeavours. Far-right groups furthermore tend to see academics as untrustworthy or hostile, and are generally wont to prevent their presence within their environments 5 .

5 Kathleen M. Blee edited a special issue of the Journal of Contemporary Ethnography, called 'Ethnographies of the Far Right', in which we find a number of ethnographic experiences with far-right groups (Journal of Contemporary Ethnography, Ethnographies of the Far Right, University of Pittsburgh Volume 36 Number 2 April 2007, 119-128 @ 2007 Sage Publications 10.1177/0891241606298815 http:/|jce.sagepub.com hosted at http://online.sagepub.com). 
In the suggestively-titled article "Anthropology of the far right. What if we like the 'unlikeable' others?", Agnieszka Pasieka (2019) asks: "how do we study far-right activists and their supporters?". The article refers to the difficulty encountered by anthropologists who intend to study the far right, and the lack of attention given to the many methodological and ethical issues it raises. Pasieka observes that the greatest fear of anthropologists in these contexts is often not that they will be repelled by the subjects they encounter, but, rather, that they may discover an interlocutor who thinks for herself and who becomes close, even while disagreeing with her political premises. Since anthropologists endeavour to create bridges for mutual understanding and dialogue, to generate familiarity where they find exoticism and difference, they are naturally more inclined to understand the reality of the other and what makes this other assume certain social and political positions. Pasieka further comments that anthropology is capable of taking people seriously, and of recognizing that there are more discrepancies between what people say and what they do, and that these inconsistencies and contradictions must also be taken seriously.

Alexandra Poli and M. Onur Arun (2019; 2021) argue that multiple factors feed into a process of political radicalization, including psychosocial factors, cultural determinants, international relations, the role of the media (and particularly of the internet), the breakdown of social ties, political circumstances, prison environments, and, in some cases, an attraction to charismatic personalities. The authors question, in principle, a causal relation between socioeconomic inequalities and the rise of radicalisms $s^{6}$. Relying on meta-ethnographic synthesis (MES), a qualitative methodology, they demonstrate, through studies of Islamic radicalization and far-right politics, that this relation is highly ambiguous (Poli and Arun 2019; 2021). Their studies reveal a tension between the objective and subjective dimensions of inequality, which can lead individuals to follow down a path toward radicalization. The subjective meanings of inequality - that is, the perception that someone is disadvantageously positioned in terms of relations of power, regardless of whether or not this feeling, perception, or sense of injustice is associated with a concrete situation - replace the objective variables of inequality. This sense of inequality engenders experiences of injustice that are interpreted, and potentially engaged, by means of various other factors, including the socioeconomic situation, individual precedents, family ties, and national context. The authors also criticize the tendency to reify the link between social inequality, religion, and radicalization, which tend to project stereotypes that harm intervention in important social issues for the affected populations, such as discrimination, racism, inequality (Poli and Arun 2019:5). In analyses of the far right, many researchers have honed in on the religious aspect, particularly on fundamentalism (Frigoli and Ivaldi 2017). These studies mostly discuss the relations between religion and the secularity of the state, and the political weight that this has assumed in recent years (Garma Navarro 2020; Almeida 2019).

Anthropology has more to contribute to studies of the far right than ethnography and access to the 'other'. It is important to stress its contributions to an understanding of a new aspect of this far right, to wit, its identarian and cultural construction, and how it appropriates concepts from anthropology to this end. Sylvan Crépon (2001), for example, notes an appropriation of anthropological words and concepts among youth militants of the Front National, a French far-right ${ }^{7}$ political party. She traces how the notion of 'national identity' is translated in terms of 'cultural belonging'; how the nationalist expansionism of the period of colonization is rejected in favour of a respect for the integralness of peoples' culture; how biological hierarchies are described in terms of cultural relativism; among other features. As Crépon explains, these young people no longer focus on the superiority of races or on colonial expansionism, but, first and foremost, underscore a cultural relativism tied to the preservation of the specificities of each people. For this far right, cultural origin determines access

6 On inequality and the far right in the context of the Brazilian government, see Negri (2021).

7 The Front National changed its name to Rassmblement National, a change that was accompanied by important modifications in its presentation and sphere of activities. The change is linked to the growing influence of Marine Le Pen at the head of the party. For further information, see Fernández-Vázquez, 2021 
to nationality and structures hierarchies. According to the slogan promoted by the youth of the Front: "Être français ça s'hérite ou ça se mérite" (being French is inherited or earned). It may be said that this study harks back to some of the founding debates of anthropology concerning the place of cultural relativism, but here we find them instrumentalized by the far right.

A review of the literature on the far right, particularly the anthropological literature, therefore reveals a consensus: the far right has an anti-pluralist character, generally manifested in its rhetoric and racist, discriminatory, and xenophobic attitudes, along with an ethno-nationalist anchoring, a staunch defence of traditional values, of the family, and of religious fundamentalism. The phenomenon is thus best defined by, precisely, the suppression of differences, a hatred of the other, identarian closure, and a strengthening of the identity of national elites. It should be stressed that the denial of the other must be comprehended within a global context in which, particularly from the 1990 os onwards, multiculturalist policies emerged alongside the rise of new demands for ethno-cultural and racially-based rights and new social movements.

\section{The far right and multiculturalism: ethno-racial particularisms}

Although the rise of the Brazilian far right has historical and cultural specificities, such as authoritarianism and structural racism, the international and global context provides the space in which it flourishes. It benefitted from the speed with which ideas and fake news circulate through social networks, allowing global tendencies to be accessed locally. Furthermore, the global expansion of neoliberalism, the struggle for resources, particularly natural resources, the consolidation of global elites, as well as the persistent influence of international agencies, all have a direct impact on local political dynamics and on the reach of values and ideologies. This context offers up the far right as a possibility for political agency against the disenchantment of particular social groups.

There are other facts that corroborate the part played by international influence on the expansion of the far right, which is consolidated by means of networks between authoritarian leaders and their political parties. For instance, the congressman Eduardo Bolsonaro, son of the president, participated in a webinar with Santiago Abascal, the head of the Spanish Vox Party, in November 2020 during an event promoted by the party's recently created Fundación Disenso. Previously, at the start of 2019, he met with Viktor Orbán, Prime-Minister of Hungary, and with the Italian Deputy Prime-Minister Matteo Salvini ${ }^{9}$. In July 2021, Brazilian newspapers showed the Bolsonaro-supporting congresswoman Bia Kicis (PSL-DF) proudly pictured with the German Congresswoman Beatriz von Storch, of the far-right party Alternative for Germany (AfS), the largest German conservative party ${ }^{10}$. The links between President Bolsonaro and his son with Donald Trump are well-attested.

Taking this global context into consideration offers challenges to sociological analyses of these phenomena. As Greig Calhoun and Michel Wieviorka (2013: 25) warn, globalization as a worldwide phenomenon requires that we broaden the perspective of sociological analysis to a range of other local and global landscapes. Similarly, globalization articulates with the individual and her subjectivity, this multiple subject with diverse identities, who moves across the global universe. Michel Agier (2013) also suggests that accelerated individualization, homogenizing processes of globalization, constant contact between local and global contexts, and the rupture of borders, cultures, and identities, have led to important changes in the practice of anthropology. In what pertains to identity, Agier (2001) explains that, while globalization brings in its wake homogenising processes, creating feelings of loss of identity, it also causes a compensation for this loss by seeking out or creating new contexts and rhetorics of identity.

8 https:/valor.globo.com/politica/noticia/2020/11/28/vox-da-ultradireita-espanhola-o-novo-flerte-ideolgico-de-eduardo-bolsonaro.ghtml

9 https://oglobo.globo.com/mundo/eduardo-bolsonaro-vai-hungria-italia-encontrar-lideres-da-extrema-direita-23604704

10 https://brasil.elpais.com/brasil/2021-07-22/extrema-direita-mundial-estreita-lacos-com-governo-bolsonaro-que-segue-passos-de-orban-e-trump.html 
'Hybrid' or 'mestizo', culture is now more than ever dominated by the problem of identity, which is increasingly affirmed to be a "cultural identity".

Processes of globalization cause rapid transformations in different cultures, threatening the dissolution of traditional forms of community. Re-adequations and appropriations, reactions to these transformations, take the community along a path of change away from its traditional format, which, in turn, forces it to recreate and strengthen new forms of identification to resist the growing threat. Using Bauman's work, Díaz-Polanco suggests that the concept of 'identification' is more adequate to this globalizing and homogenizing system, since it more easily adapts to this scenario. By failing to overcome the individualization that aggravates the system, identification creates the illusion of a redemptive community - that is, it creates an image in the very goal of the global creative logic, or in an already globalized conglomerate. What would thus emerge is a cosmopolitan identity that masks a process of individualization (2006: 147).

Permanent contact between different peoples, particularly between people in movement in the European and North American contexts, once again raises issues of xenophobia, discrimination and racism. According to some authors, racism is transformed in certain contexts, taking on more "differentialist" features based on an affirmation which is likewise cultural (Wieviorka 2017). In Latin America, we once again find structural racism, historically directed mostly toward Afro-Americans and Indigenous people, gaining ground in public discourse through the new authoritarian rhetoric. However, contemporary racist discourse is born in opposition to these populations' condemnation of this structural and historic racism, which had been formerly rendered invisible, camouflaged.

In this global landscape, conservative and dominant positions exist against a wide range of sectors that resist them in search of social recognition. We are no longer faced with a "clash of civilizations", as Samuel Huntington had predicted, but with an encounter of diversity in individuality, in a multiplicity of cultures that cohabit the same national and global space - a space which is marked, first and foremost, by the pervasiveness of Capitalism.

The debate concerning the rights of ethnic minorities takes centre stage in the 199os. It is not that there were no ethnic conflicts previously, or no process of exploitation, as attested by European colonization itself. In the 1990s, however, societies that were oppressed and colonized begin to interpolate colonial powers, resulting in concrete and focused public policies. Kymlicka (2003:30) proposes some reasons for the surge in ethnonationalist movements in Eastern Europe, among which he includes the fall of Communism. Other factors recur in many Western democracies: a narcissistic retrogression against migrants and refugees, the re-emergence of Indigenous people and their political claims in national and international landscapes, and growing demands for autonomy and separatist proposals, in countries such as Canada, Great Britain, Belgium, and Spain. These phenomena reached a decisive moment in the 199os, making it evident that western democracies had been unable to overcome the tensions that emerge from ethnic and cultural diversities. Hall (2003:55) further argues that this is the result of a strategic reconfiguration of global forces and social relations. One important change is the end of the old European imperial system and the emergence of struggles for decolonization and national independence. New multi-ethnic and multicultural nation-states were created, but they continued to reflect the inequality and subjugation experienced during the colonial period, restructured by the liberal world economy.

In Latin America, during the last decade of the $20^{\text {th }}$ Century, ethnicity also became central to public debate, bolstered by three factors: the emergence of Indigenous political movements, nationally and internationally, during the 1980s and 1990s; the development of international jurisprudence on Indigenous rights as elements of Human rights; and the constitutional reforms which took place throughout the region, and which recognized the multicultural character of Latin American societies (Sieder, 2002). 
Gros (2000) also proposes structural causes that enabled an "Indigenous awakening" in Latin America. The author stresses the crisis of the peasantry, population growth, the expansion of national society, and the advancement of formal education in Latin American countries. On top of all of this is the crisis of the national-populist project, starting in the 1970s, which was ultimately unable to promote the integration of Indigenous people. A further attenuating cause was the intervention of foreign agents which, for different reasons, acted on communities and oriented their acts toward the assertion of differentiated identities. These actors include missionaries, militant politicians, anthropologists, human rights activists and, in particular, Indigenous rights activists, NGOs, and other conveyors of new rhetoric and of important financial resources, acting as mediators between communities and the wider world.

Starting in the 1990s, we witness the emergence of a project for multiculturalism which seeks to accommodate existing cultural plurality and its demand for rights, no longer privileging state-run projects aimed at development and the construction of a state of social well-being. Multiculturalism is diverse, of course, both in how it is understood and applied by different countries. In the Brazilian context, we find a preference for promoting policies that favour racial equality, including affirmative action aimed mostly at the Black and Indigenous population. In what pertains specifically to Indigenous and Maroon peoples, we witness a turn to multiculturalism in their demands for cultural rights and claims over their traditional lands, as inscribed in the 1988 Constitution.

Multiculturalism, as an element of a philosophical current, cannot be apprehended monolithically. It emerges from, and transforms within, debates and discussions between different strands of thought. It became consolidated in more liberal versions, such as the liberal culturalism of Kymlicka (2003: 63), or in more critical tendencies opposed to a liberal Eurocentric perspective. Recent reviews highlight the advances that have been made, particularly in national and international legislation that recognizes a diversity of ethnic/cultural and racial rights. When these rights are to be put into practice, however, they often encounter hurdles (Sierra and Igreja, 2020). This difficulty is seen to result from the appropriation of multiculturalism by neoliberalism, instrumentalizing it within a project of decentralizing the state, favouring social fragmentation, and advancing transnational economic interests. This neoliberal multiculturalism is structured to strategically reorganize ethnic demands, avoiding conflicts that might lead to political and juridical instability for the Capitalist system, thereby creating barriers between cultural rights and control over the resources needed to exercise these rights. At the same time, they promote the suppression of social movements and the control over identity politics, legitimizing certain groups and identities that meet their interests (Hale 2005: 13).

The rise of the far right once again puts the debate surrounding multiculturalism on the agenda. Some authors consider that we are undergoing a decline in multiculturalism, experiencing a context with an increment in intolerance and racism, in which there is no longer any interest in recognizing and organizing diverse racial and cultural identities (Lins Ribeiro, 2018; Wieviorka, 2015). However, I believe that what we are witnessing is not so much multiculturalism's decline, but the acceleration of ethnic and anti-racist demands, which now exceed their own management capacities. Resistance movements differentiate themselves throughout the world, new ethnic, gender-based, and anti-racist demands crop up, urging legislative change and new policies. These changes are also occurring in academia, where new theoretical and empirical perspectives on the study of gender have emerged. Particularly apposite to the current discussion are studies of Indigenous and Black feminisms, as well as racial and ethnic studies. An interesting example are the recent attacks on Critical Race Theory (CRT), particularly on Professor Kimberlé Crenshaw (Crenshaw et al., 1995), by the North American far right. Taking its cue from legal studies, CRT reflects on the permanence of structural racism in the United States, and how this condition perpetuates the inequalities that affect African-Americans. 
As reported in newspapers, and attested in reactions by politicians and supporters of the far right in the country, CRT is seen to be a Communist proposal which generates division, holds whites culpable, and even promotes white genocide ${ }^{11}$.

The far right comes to prominence in a climate of fear and insecurity, when the demands of other cultures and other peoples gain ground, as do those of feminists and LGBTQIA+ groups, threatening a purported traditional and conservative order. The far right mobilizes culturalist rhetoric and identity politics, as Crépon notes, in the hope of reclaiming its spaces, seeking out allies, making concessions and building consensus. The far right reacts to multiculturalism by redefining itself according to its own principles. Rydgren, for instance, explains that the European far right emerged alongside social and political movements linked to new parties (green parties and new left-wing parties). The author thus laments that analyses of the far right have been carried out only by those who are narrowly specialized on the theme, and who thus fail to include in their analyses perspectives stemming from the field of social movements, network analysis, and ethnic relations. Studies of the far right have much to gain from considering its rise in this multiculturalist space of ethno-racial insurgency.

\section{"Alterity" in the Bolsonaro Government: the president and Indigenous peoples}

The June 2013 protests in Brazil were a turning point in the Brazilian political landscape, directly contributing to the election of president Jair Bolsonaro. Discontentment with institutional politics became explicit, and voters' disappointments were mostly geared towards the Workers' Party (Partido dos Trabalhadores, PT), which had been in power since 2003. These disappointments were, however, based on a social structure of prejudice - of gender, class, race, sexual orientation - including various misogynist, elitist, racist and homophobic expressions that further augmented the conservative movement, making the left, and in particular the PT, into national enemies.

Bolsonaro was at the time was an inexpressive congressman on his seventh mandate who adopted his usual strategy for grabbing media attention with provocations, exaggerations, and effrontery, buttressed by his humourful act. He thus materialized as an avatar of voter disenchantment. Bolsonaro's election victory, and the support he sustained during his first years in power, resulted from his characterization and depreciation of the 'establishment' (often linked to categories such as 'the Left', 'communists', political correctness, progressiveness, homosexuality, corruption, and immorality), his self-portrayal as the only anti-establishment candidate (austere, sincere, and out of synch with the formalisms of traditional politics), and his mastery of the idiom of social networks as a tool for constructing these meanings (colloquial language, informal behaviour, face-to-face interactions with voters).

Bolsonaro comes to power promising a vast cultural and moral reform of the country, and the recuperation of Christian and family values. To this end, he presents himself as a radical opponent of identity politics and progressive policies, which came to be identified as a strategy of ideological domination by the international left, as a moral and ideological subversion of traditional Brazilian culture. With his constant posturing, conservatism, and cruelty in his dealings with opponents, he appears in news outlets as a reactionary, histrionic and controversial figure, not least because of his admiration for Brazil's Military Dictatorship. Like other far-right leaders, Bolsonaro upholds the recovery of an idealized past, in this case of the old military regime.

11 This is a recent phenomenon, reported mostly in periodicals. Cas Mudde, a specialist on the far right, recently wrote on theme (see: https://www. theguardian.com/commentisfree/2021/jun/25/critical-race-theory-rightwing-bogeyman-left-wing). For other sources, see: https://www.adl.org/blog/extremists-see-critical-race-theory-as-evidence-of-white-genocide; https:/www.americanbar.org/groups/crsj/publications/human_rights_magazine_home/ civil-rights-reimagining-policing/a-lesson-on-critical-race-theory|; https:/www.newyorker.com/news/annals-of-inquiry/how-a-conservative-activist-invented-the-conflict-over-critical-race-theory 
In my research, I initially sought to elaborate a framework for analytical categories based on Bolsonaro's discourse in social networks and in his official speeches (Igreja and Negri, 2020). This showed that his manifestations expressed the following characteristics: anti-democratic sentiment; pro-military views, in defence of widening access to guns in a tone of violence and repression; electoral touting in an ultraliberal and moralizing tone, including regular attacks on LGBTQIA+ populations; anti-left and anti-political stances, loathing politics and political parties; an anti-media position, critical of 'press bias'; an anti-minorities view, constantly demeaning Blacks, Indigenous peoples, landless peasants, women, the unemployed, the homeless, immigrants, prison inmates, criminals; and, finally, anti-cultural tendencies, with specific attacks on artists.

In his plan for government, Bolsonaro calls for the liberation of the Brazilian people from cultural Marxism, which indoctrinates students and subverts traditional values of the family and democratic principles. According to the president, the Left tried to deconstruct the backbone of the Nation. Somewhat confusingly, the Bolsonaro government and its followers subvert the meanings of 'democracy' and 'liberty', as if these had been dominated by a left-wing populism and by the undemocratic values of communism. For Bolsonaro, democracy and liberty are to be found in the right to private property, in liberalism, in gun ownership, in the freedom of the family without interference by the state, in Christian freedom and in a critique of the secular state. On the basis of these views, he would structure his government to attend to the interests of "good Brazilians", that is, true Brazilians, the representative of the people, in contradistinction to the "bad Brazilian". Those who are unhappy can leave the country, or wait for another election and/or another president.

Free Brazil

We propose a decent government, different from all that has cast us into an ethical, moral, and physical crisis. A government with no give-and-take, no bogus deals. A government made up of people committed to Brazil and Brazilians. One which attends to the yearnings of citizens and works towards what actually makes a difference in the lives of us all. A government that reclaims the most precious good of any citizen: Freedom. A government that will return the country to its rightful owners: Brazilians. (Bolsonaro plan for government, 2018).

This way of defining the Brazilian people coincides with the rhetoric of populist leaders, as we have seen above. However, defining those that correspond to an ideal 'good' Brazilian, in contradistinction to the 'bad Brazilian', the traitor to the homeland, is not so simple. Although Bolsonaro offers a binary perspective, establishing a cleavage between those whom he considers citizens and those he does not, these categories are motile and only exist in interrelations with others.

According to the president, Brazilians are Christians, Evangelists, patriotic, military (which, more than a career, is a virtue), liberal, heads of families, honest, loyal, true, hard-working, defenders of liberty, of private property, of agribusiness, of democracy, of the traditional family, representatives of a united people, a majority. The bad Brazilian is a leftist, supporter of the Workers' Party, a communist, corrupt, militant, a bum, thief, terrorist, politically correct, a journalist, environmentalist, a minority, upholder of gender ideology (the devil itself). These categories must be apprehended not in isolation, but in interrelation. In Bolsonaro's proposal for cultural and moral reform they go hand-in-hand, complementing each other. We must ask, for instance, where, in this idealized and fictitious image of a homogenous Brazilian people conjured by the president, do Indigenous and Afro-Brazilian people fit in?

It is equally important to understand that this symbolic construct of a purported 'true Brazilian' is propagated on a stage of public disputes between the conservative proposal of the government and the advancement of progressive forces. We therefore draw attention to the need to analyse the far right in connection with opposite progressive forces that grow and gain ground in the country; indeed, the former models itself within this context. On one side, the Bolsonaro government assembles conservative right-wing forces, represented by the 
rural oligarchies that have always been in charge of the country, by neoliberal businesses that defend a small state and labour and administrative reforms; the conservative and traditionalist middle classes; by believers, particularly Evangelists; and by those who are disenchanted with the Left - in brief, a motley group which converges towards the president because of his neoliberal agenda and/or his moralizing and conservative view of custom. They come from sectors concerned with the loss of economic and social privileges, or with the loss of traditional Christian values threated by an agenda that is linked, most of all, to issues of gender identity.

On the other side are more progressive groups, also heterogenous, which converge on the defence of human rights, identity policies and anti-racist agendas, environmental concerns, and a stronger state presence. After many years of democratization and a left-wing government, the reinforcement of women's rights and those of the LGBTQIA + community, as well as rights of Blacks and Indigenous peoples and the widening of social inclusion through targeted policies, affirmative action along racial and ethnic lines, and, consequently, a growing Indigenous and Black presence in education, the elites reacted by trying to safeguard their historical privileges. To this end, they tapped into discontentment with former left-wing governments, which failed to adequately attend to expectations of part of the population. In the midst of this binary division are social groups that oscillate between these agendas, and who, even if they do not vote for Bolsonaro, agree with some of his views, particularly in what pertains to social privileges and traditional values. To understand these positions we must consider the history of authoritarianism, patrimonialism, inequality and structural racism in the country (Schwarcz, 2019). In this contested field, the government manipulates speech, makes full use of the reach of social networks, promotes fake news and street manifestations, and stokes political disputes in the National Congress and the Supreme Court. The current context of the Covid-19 pandemic makes these conflicts over views of the state and society all the more evident. Although the president's popularity has been declining, mostly due to his disastrous handling of the pandemic, he still has significant popular support and can still be assured of a steady vote in the National Congress for elements of his political agenda.

To put his conservative government into practice, Bolsonaro carried out a ministerial reform which is revelatory of his fundamental principles. In specific, he created the Ministry of Women, Family and Human Rights under the leadership of Damares Alves, a conservative woman, pastor, and one of the most important personalities of Bolsonaro's government. This ministry is in charge of the National Office of Policies for Women, the National Office for the Family, the National Office for the Rights of Children and Adolescents, the National Office for Youth, The National Office for the Promotion of Racial Equality, among others. Damares Alves praises the president for having pioneered a ministry for the defence of the family, a guiding thread for the government.

It is also possible to analyse this conservative project by how it resignifies Indigenous alterity. This has been the main focus of the research I have been carrying out with my team: observing how the government considers, represents and situates Indigenous people in its project for Brazil. This analysis furthermore sheds light on that premises and values that guide the government. Indigenous people have been at the centre of attention, mostly for strategic economic reasons related to the exploitation of Amazonia. A first step in this research involves a review of a number of documents and strategic plans of the different ministries in relation to the Indigenous population, records of meetings, recordings of encounters between the president and the president of the National Indian Foundation (Fundação Nacional do Índios - FUNAI) with Indigenous leaders, many of which are available in FUNAI's website. We also had recourse to newspaper reports and blog posts which the president links in his social network accounts. A second step will involve ethnographic fieldwork, but the pandemic has led to delays and, for now, forced us to develop research at a distance ${ }^{12}$.

12 My research team has been in touch with Indigenous leaders, particularly those who meet in Brasilia to take part in anti-government protests. This dialogue will hopefully elucidate an Indigenous perspective on the government, and also on national politics and democracy. At the same time, we are interested in accompanying their often-contentious meetings with government authorities. 
As I mentioned above, Bolsonaro's speech manifests his disdain for Indigenous peoples and their culture, and it has done so ever since he was a congressman. He advocated for an end to the demarcation of Indigenous Lands, all the while being complicit with the invasion of federally recognized lands. In the company of an Indigenous woman, Ysany Kalapalo, a youtuber from village of Tehuhungu, situated in the Xingu Indigenous Park in Mato Grosso, Bolsonaro proclaimed, in the $74^{\text {th }}$ General Assembly of the United Nations:

Today, $14 \%$ of the Brazilian territory is demarcated as Indigenous Lands, but we must understand that our natives are human beings, exactly like any one of us. They desire, and deserve to, enjoy the same rights as all of us. I want to be clear: Brazil is not going to increase the extent of demarcated lands to $20 \%$, as some of heads of state want us to. We have, in Brazil, 225 Indigenous people, and references to 70 tribes living in isolation. Each tribe or people has its chief, its culture, traditions, customs, and, in particular, its way of seeing the world. The view of one Indigenous chief does not represent that of all Indigenous Brazilians. Very often some of these chiefs, such as chief Raoni, are used as patsies by foreign governments in an informational war with the aim of imposing their interests in Amazonia. Unfortunately, some people, both in Brazil and abroad, supported by NGOs, insist on maintaining our Indians as veritable cavemen. Brazil now has a president that is concerned with those who have lived there since before the Portuguese arrived. The Indian does not want to be a poor landowner of rich lands. Specially of the richest lands in the world. This is the case with the Yanomami reservations and the Raposa Serra do Sol. These reservations have a large quantity of gold, diamond, uranium, niobium and rare soils, among others. And these territories are enormous. The Yanomami Reservation alone is approximately ninety-five thousand square kilometres, about the size of Portugal or Hungary, though only fifteen thousand Indians live there. This shows that those who attack us are not interested in the Indigenous human being, but rather in the mineral wealth and biodiversity of these areas. The United Nations had a fundamental role in overcoming colonialism, and it cannot accept that this mentality returns to these rooms and corridors, under any pretext (emphases added)

This statement was reaffirmed by Bolsonaro in January 2020, during his weekly live, which focused on the creation of the Council for Amazonia, which would be charged with defending sustainable development, and, in his words, the "Indigenous reservations". The president stated:

The Indian has changed, he's evolved... Increasingly, the Indian is a human being just like us. So let's make sure that the Indian is integrated into society and really becomes the owner of his Indigenous lands, this is what we want here ${ }^{14}$.

Such statements repeatedly stress that Indigenous peoples are human beings; owner of the land, but poor since they are unable to exploit it economically; the Indian wants to evolve. The president presents himself as a defender of Indigenous peoples against the interests of NGOs that inhibit them in their path toward evolution, according to the parameters and values of Brazilian society and economic liberalism.

These ideas make themselves concertedly present in other spheres of government. In a ministerial meeting held on the $22^{\text {nd }}$ of April 2020, the then-Minister of Education Abraham Weintraub claimed:

This country is not... I hate the term "Indigenous people", I hate this term. Hate it. The "gypsy people". There is only one people in this country. Those who are good with this, are good; those who aren't, hit the road. It's the Brazilian people, there is only one people. You can be Black, you can be White, you can be Japanese, you can descend from Indians, but you have to be Brazilian, man! Let's put an end to this business of people and privileges. There can only be one people, we can't have ministers who think they're better than the people.

13 https://agenciabrasil.ebc.com.br/politica/noticia/2019-og/presidente-jair-bolsonaro-discursa-na-assembleia-geral-da-onu

14 https:/|www.youtube.com/watch?v=WX7Xrs2 $33 \mathrm{QY}$ 
It is equally interesting to observe Minister Damares Alves' curriculum vitae, available in the website of her office:

Working in the National Congress for over twenty years, the lawyer is considered to be an authority in combating paedophilia and protecting children. She gives pride of place to the voices of thousands of children with special needs, victims of Indigenous infanticide. She has advocated pro bono for many years, for women and children in vulnerability and who suffer from domestic violence. ${ }^{15}$

Despite recognizing Indigenous languages and cultural diversity in Brazil (which she refers to as 'a mix of race, colour and language') in official events, the Minister highlights, in her curriculum vitae, the matter of the "thousands" of children who have special needs, victims of Indigenous infanticide, thereby reproducing hate speech against Indigenous people.

In April of 2019, President Bolsonaro met to discuss development projects in the offices of FUNAI with Indigenous leaders from the Pareci (Mato Grosso), Macuxi (Roraima), Xucuru (Pernambuco), and Yanomami (Amazonas/Roraima) peoples. In this meeting, Bolsonaro makes it clear that he wants to speak to Indigenous people in the absence of intermediaries. The authorities present insisted that the Indigenous people would be treated as any citizen; they would have access to funds for productive activities and technical support for mining (which, they insist, should never be referred to as 'panning'). Bolsonaro mentions his experience visiting Indigenous village, and how he was impressed with their poverty, precarious health conditions, and lack of resources. For the president, this poverty is unjustifiable considering the wealth that the lands possess. Criticizing the Left, the president tells the Indigenous leaders that Brazil needs everyone to work for the country and that there is no reason they should want to remain poor, enslaved by NGOs or political parties. The president says he wants their freedom.

The Indigenous leaders who met with Bolsonaro wanted to discuss better living conditions, education and healthcare. They make it clear that their goal is to seek out better ways of using the land without prejudice to their culture or to the environment. The Bolsonaro government interprets these demands within a neoliberal and developmentalist framework, as evident in the actions of the government which display little regard for the protection of Indigenous Lands, their environment and culture. Indigenous policies in the country are undergoing new challenges in a moment of rapid change. The pandemic, migration to urban centres, illegal invasion of Indigenous Lands, cessation of processes for demarcating lands, and poverty, all of this stands out in a context in which neoliberal policies are being exacerbated and development and infrastructure projects in Indigenous Lands are picking up speed.

Yanomami leaders replied to the president by reaffirming their commitment against mining in their territories, and explaining that have wealth in the forest, and are therefore not poor: "you say that the Yanomami are hungry and suffering. We, Yanomami, none of us are suffering. No one is hungry", according to Davi Yanomami, an important Yanomami leader. Yanomami leaders also challenged the words of Timóteo Yanomami, who had taken part in the meeting with the president ${ }^{16}$.

FUNAI puts the president's position into practice. Its current head, Marcelo Augusto Xavier da Silva, a federal police sheriff, claims to defend Indigenous autonomy. In a live with the president on the $29^{\text {th }}$ of April 2021, the head of FUNAI said that the agency was providing incentives to a range of ethnodevelopment projects, claiming that "the Indian does not cease to be an Indian because he seeks better living conditions. The Indigenous people must be protagonists of their own history, with no intermediaries".

15 https://www.gov.br/planalto/pt-br/conheca-a-presidencia/ministros/ministerio-da-mulher-familia-e-direitos-humanos

16 https:/|www.socioambiental.org/pt-br/blog/blog-do-rio-negro/yanomami-respondem-bolsonaro-nao-somos-pobres-e-nao-queremos-garimpo 
He also underscores Indigenous freedom and autonomy: "It is Indigenous people themselves who have to say what model of activity is to be implemented in their villages" ${ }^{{ }^{17}}$.

Equally indicative is Bolsonaro's speech in a visit to Yanomami communities in May of 2021, in which he claims to respect their wishes. If they did not want mining activity in their lands, then there would be no mining activity in their lands: "There are other Indian brothers, in Amazonia and outside of it, who want to mine the land, who want to cultivate the land, and we're going to respect their rights" ${ }^{{ }_{18} 19}$.

In another video recorded in the same month in Matucará, Amazonas state, posted by the president in his personal Facebook page ${ }^{20}$, Bolsonatro speaks to a number of Indigenous peoples, repeating the same lines about 'our brothers' and how others do not allow them to evolve. Indigenous people demand autonomy over their lands, better living conditions, and access to education and the internet. The president once again uses these demands as a springboard for promises of development, particularly through planned partnership for land leasing to mining interests and agribusiness. Not wearing a mask in the height of the pandemic, the president asks the Indigenous people gathered with him if they are protecting themselves from Covid-19. Upon hearing that they make use of traditional medicines, he links traditional medicines to his preferred "preventive treatment" with chloroquine and ivermectin ${ }^{21}$. The video concludes with an Indigenous child praying with the president. His support with sectors of Evangelical Churches has been crucial for bolstering his influence. This video has English subtitles, serving as a demonstration to foreigners of Bolsonaro's 'positive' relation with Indigenous people (in contrast to the video with the Yanomami, in which he promises not to provide incentives to mining in their land, which lacks subtitles).

Many of the comments that the president's supporters left on this post thank him, implying that he is the only president to really care about Indigenous people, recognizing their humanity, understanding that they deserve autonomy and should be integrated. A steady religious discourse is also evident, with posters thanking God for the president as a representative of traditional Christian values. There is equally an insistence on the need for Indigenous peoples to evolve, to respect laws like any citizen, and that their evolution must trace a clear path toward economic freedom geared to the market. These views attest to a lack of understanding of cultural difference and a discrimination against Indigenous ways of life. These ideas clash with the Constitutional rights of Indigenous people and re-signify Indigenous autonomy.

Congratulations to our Indigenous brothers! I want to see all of you very happy and in peace! Preserving our nature with love and gratitude, but we must all evolve, and evolution does not mean devastation, all in in good measure for everything and everyone! The internet and information, health and education for all! (posted by a supporter of the president).

Many want our brothers to live like their ancestors did 521 years ago. The Brazilian Indian is like all of us. They want to live like us. An Indian is not an animal in a zoo. (posted by a supporter of the president).

The president's rhetoric reflects positively on many of his supporters, in stark contradiction to his actions which reveal a drive towards removing protections and the rights of Indigenous people over their lands. Statements by members of the administration tend to replicate violence and conflict among Indigenous peoples.

\footnotetext{
17 https://www.gov.br/funai/pt-br/assuntos/noticias/2021/autonomia-indigena-e-destaque-na-live-do-presidente-jair-bolsonaro

18 https://www.youtube.com/watch?v=GavqXqw2oqw

19 In the institution's webpage we find a selection of videos of meetings with Indigenous peoples, as well as the president's 'lives' with representatives of FUNAI.

20 https://www.facebook.com/jairmessias.bolsonaro/videos/3020996651555199/

21 Youtube removed the video from its site, considering that it allowed the president to prescribe inefficient medication for Covid-19.
} 
In a video posted by the Folha de São Paulo in July 2021, the head of FUNAI in the Vale do Javari (Amazonas state), the reserve lieutenant of the Armed Forces Henry Charlles Lima da Silva, encouraged leaders of the Marubo people to fire against uncontacted Indians in case they are "pestered" by them. "I'm going to contact the people in the Front [the Ethnoenvironmental Protection Front of the Javari Valley] and put the pressure on them: 'you have to take care of the isolated Indians otherwise I'll join the Marubo and fire on them', said Henry during a meeting at Paulinho village on the $23^{\text {rd }}$ of June $e^{22}$.

The Articulation of the Indigenous People of Brazil (Articulação dos Povos Indígenas do Brasil; APIB) organizes and participates in manifestations against the president and his policies for Indigenous affairs. The Xavante Warã Association, for example, complains of the president's promotion of Indigenous cooperatives and the exploitation of their lands:

"It is further stimulus to dependency and the leasing of our lands, with a clear air of illegality. We know that the ultimate aim of this project - which is political - is to appropriate our territory, under the false and hypocritical pretences of the economic development of our communities. Old arguments for new claims on our rights and territory. It is the siege of agribusiness on the savannah, and all of its projects of roads, hydroelectric dams, and railways, which destroy the way of life of the Auwé Xavante people in the Ró/Savannah, our way of life, bringing disease and death", says the organization ${ }^{23}$.

In defence of their rights, more than one thousand Indigenous people camped in the "Uprising for Land" (Levante pela Terra") in Brasília to follow Supreme Court ruling and the votes in Congress. These representatives of the Indigenous peoples of Brazil remained in Brasília to ask for the nullification of the 'temporal marker' ${ }^{24}$ and to oppose bill $490 / 2007^{25}$, proposed by congressmen linked to agribusiness, and which alters the demarcation of Indigenous Lands. Political manifestations, and pressure on the National Congress and the Supreme Court, are tools available for the struggles of Indigenous peoples. In contrast, channels for dialogue with the head of FUNAI are now restricted to those Indigenous people who are interested in government proposals and who are not representative of the majority of Indigenous people in the country.

\section{Concluding remarks}

Research on the Bolsonaro government in Brazil leaves no doubt concerning the populist tenor of the president's far-right government. His anti-pluralism, his insistence on a conception of unified and unitary people morally defined, on traditional and religious values, and on the vindication of the family, all attest to this character. Furthermore, the president's neoliberal rhetoric approximates him to other far-right leaders who adopt the same agenda.

However, classifying him as a 'populist' does not appear to be enough to understand how he is able to attract broad, heterogenous and diverse social sectors. The manipulation of his discourse, use of the internet and fake news, certainly contribute to this process, but we must consider that it is insufficient.

\footnotetext{
22 https:/www1.folha.uol.com.br/poder/2021/o7/tenente-do-exercito-coordenador-da-funai-fala-outem-meter-fogo-em-indigenas-isolados-no-am-ouca-audio.shtml

23 https://www.brasildefato.com.br/2021/07/16/cooperativa-de-agronegocio-divide-indigenas-xavante

24 The 'temporal marker' (marco temporal) is a legal thesis, upheld mostly by those with interests in agribusiness, that restricts the constitutional rights of Indigenous peoples by determining that only those people who occupied their land on the 5 th of October 1988, when the Federal Constitution of 1988 was ratified, have the right to demarcation of their lands. The temporal marker is being judged in an appeal to be considered by the Supreme Court, and in the Projeto de Lei (PL) 490 .

25 https://www.camara.leg.br/proposicoesWeb/fichadetramitacao?idProposicao=345311
} 
We must also seek to understand how the president and his team think, what they say, how they act, the strategies they use and how they establish dialogue with their audience. It is to this end that we rely on anthropology and its methodological tools, seeking to account for the complexity of the phenomenon.

This article's review of recent anthropological studies is meant to help us in the development of our research. As I have shown, anthropologists who study populism and the far right stress the importance of their discipline, since their theoretical and methodological tools enable a more fine-grained study of the profiles of populist leaders and the dynamic field in which they operate. Furthermore, as a discipline focused on alterity, on different peoples, cultures and identities, it is well-equipped to understand how the far right relates to cultural diversity and how it defines itself through its own identity and culture.

Ethnographic fieldwork among supporters of the far right is difficult. In particular, gaining field access to supporters is complicated because of the hostile political context, as revealed in threats toward academia. The Covid-19 pandemic further muddles this landscape. Fieldwork requires time to understand the reality one observes and experiences. We therefore propose to approach the field in stages, gathering the largest amount of data available. We must account for the possibility that, perhaps, Bolsonaro and the far right will not remain in government for long; however, our focus is on investigating how their projects and rhetoric are structured, garnering followers, and which social segments and values they represent, as well as what transformations they trigger.

I have tried to show how, in their dealings with the 'other', and particularly with Indigenous leaders, the president and the head of FUNAI reveal their prejudice and racism toward Indigenous peoples, addressing them as human beings in search of evolution, appropriating their demands, such as those of autonomy and self-determination, in order to further their own agenda. To this end, they manipulate the words of Indigenous peoples, reframing their lacks and suffering to further their own goals.

It is interesting to pay attention to the identity game that the government promotes; to observe how it imposes meanings on the "other" in a manner that is typical of authoritarian populism. Plurality only exists when it converges with his government plan, and never when it emerges from social movements and their manifestations. This game furthermore repossesses anthropological conceptions and concepts, bringing debates concerning 'identity', 'culture', and 'cultural essentialisms' to the heart of politics, in the process giving them new meanings. Identities take shape as radicalized and instrumentalized identities, constructed at the borders, in engagement with the other (and here we may gain insight from the work of Fredrik Barth), where they take on this conservative, essentialist and radical aspect. Anthropology is asked to reposition itself in the face of this radicalized and essentialist appropriation, revisiting its theoretical core and cherished concepts, promoting ethnographic research, reinventing itself and adapting itself to this new context.

My studies, and those of the research group with which I am involved, also warn us of the importance of taking the global context into account. We have thus highlighted the need to go back to the theme of neoliberal globalization and its impacts on our society. Although still in its early stages, a study of the profile of the rise of the Brazilian far right shows that it is part of a wider global phenomenon, composed of a consistent expanding network.

It is likewise crucial that we return to debates on multiculturalism and its relation to the current context. While some of the authors we have analysed claim that we are living through a post-multicultural period, insofar as 'multiculturalism' has been hijacked by neoliberalism and we are witnessing a low yield in the recognition of cultural identities, and/or because there no longer seems to be any interest in promoting such recognition, it is our view that we are not seeing the end of multiculturalism, but its exacerbation against the ethnic and anti-racist demands of social movements. In this sense, 'multiculturalism' extends beyond the purview of neoliberalism. 
What we can conclude about the Brazilian far right is that it is new, in that it finds its place within the same international network of far-right parties, sharing their worldview, idiom, values and strategies. Yet it is also old, in that it adopts the same excluding, discriminatory, and racist principles that persist in our society. When we observe the far right in the Brazilian context, we realize that it represents a regressive setback, an attempt to recuperate an authoritarian past founded in slave-holding practices. What we find is the struggle for the reproduction of the age-old inequalities and hierarchies that structure Brazilian society. It is in this sense that the study of the far right cannot be isolated from analyses of inequalities in all spheres, nor from the racism and discrimination that permeate our society.

Translation: Luiz Costa

Received: July 28, 2021

Approved: August 23, 2021

\section{Bibliography}

AGIER, Michel. 2013. "Le tournant contemporain de l'anthropologie”. Socio, 1 :77-93.

AGIER, Michel. 2011. "Distúrbios identitários em tempos de globalização". Mana, 7 (2): 7-33.

ALMEIDA, Ronaldo de. 2019. "Bolsonaro presidente: conservadorismo, evangelismo e a crise brasileira". Novos Estudos CEBRAP, 38(1): 185-213.

BLEE, Kathleen M. 2007. "Ethnographies of the Far-Right”. Journal of Contemporary Ethnography, Ethnographies of the Far Right, University of Pittsburgh, Volume 36

Number 2, April.

BRIONES, Claudia. 2019. Conflictividades interculturales. Demandas indígenas como crisis fructiferas. Guadalajara, México: CALAS http://calas.lat/sites/default/files/briones.conflictivides_interculturalels.pdf.

CALHOUN, Craig; WIEVIORKA, Michel. 2013. "Manifeste pour les sciences sociales". Socio, 1: 5-39.

COMAROFF, Jean. 2011. "Populism and Late Liberalism: A Special Affinity?" The ANNALS of the American Academy of Political and Social Science, 637: 99-111

CREPON, Sylvain. 2001. "L'extrême droite sur le terrain des anthropologues. Une inquiétante familiarité". Socio-anthropologie, 10, 2001, mis en ligne le 15 janvier 2003, consulté le 14 avril. Avaiable at: 〈http://journals.openedition.org/socio-anthropologie/164〉. DOI: https://doi.org/10.400o/socioanthropologie.164

CRENSHAW, Kimberlé et al. 1995. Critical Race Theory. The Key Writings That Formed the Movement. New York; The New Press

DÍAZ-POLANCO, Héctor. 2006. Elogio de la diversidad: globalización, multiculturalismo y etnofagia, México: Siglo XXI.

DONAHUE, K., HECK, P.R. 2019, Cycles of Hatred and Rage: What Right-Wing Extremists in Europe and Their Parties Tell Us About the US; Cham, Switzerland, Palgrave Macmillan;

1st ed. 2019 edition (May 17, 2019) 
FERNÁNDEZ-VÁZQUEZ, Guillermo. 2021. "La Transversalidad en Acto: Pirateo de Figuras Históricas y Símbolos de la Izquierda Francesa por Parte del Front National de Marine Le Pen Durante el Período 2011- 2018”. In: R. Igreja e Negri (eds.), Desigualdades Globais e Justiça Social Interfaces Teóricas, Acesso à Justiça e Democracia. Brasília; FLACSO: 438-459

FERNÁNDEZ-VÁZQUEZ, Guillermo: 2019. Qué hacer con la extrema derecha en Europa: el caso del Frente Nacional. Madrid: Contextos/Lengua de Trapo.

FRIGOLI, Gilles, IVALDI Gilles. 2017. "L'extrême droite et l'islam : fractures idéologiques et stratégies électorales". Hommes \& Migrations, $1316:$ 27-34.

GARMA NAVARRO, C. 2020. "México: los nuevos caminos de los creyentes. Transformaciones en las posiciones políticas de las iglesias evangélicas, protestantes y pentecostales”. Plural. Antropologías desde América Latina Y del Caribe, 2(6): 183-206

GROS, Christian. 2000 . Políticas de la Etnicidad: identidad, Estado y Modernidad Bogotá: Instituto Colombiano de Antropología e Historia.

HALE, Charles. 2005. "Neoliberal Multiculturalism: The Remaking of Cultural Rights and Racial Dominance in Central America". PoLAR: Political and Legal Anthropology Review, 28(1): 10-28.

HALL, S. 2003. “Questão multicultural”. In: Liv Sovik (org.), Da diáspora: identidades e Mediações culturais. Belo Horizonte: UFMG/Unesco. pp. 51-100.

HANN, Chris. 2019. “Anthropology and Populism”. Anthropology Today, 35(1): 1-2.

IGREJA, R. \& NEGRI, C. 2020. "As ciências sociais brasileiras frente à ascensão da extrema-direita: uma reflexão urgente e necessária". Plural. Antropologías desde América Latina y del Caribe, 2(6): 35-69.

KULICK, D. 2003. "Anthropologists are talking' about the newright in Europe". Ethnos: Journal of Anthropology, 68(4): 554-572.

KYMLICKA, W. 2003. La política vernácula - Nacionalismo, multiculturalismo y ciudadanía. Barcelona/Buenos Aires/México: Paidós.

LACLAU, Ernesto. 2013. A razão populista. São Paulo: Ed. Três Estrelas.

LINS RIBEIRO, G. 2018. "Giro global a la derecha y la relevancia de la Antropología”. Encartes Antropológicos, 1(1): 1-4.

MAZZARELLA, William. 2019. "The Anthropology of Populism: Beyond the Liberal Settlement" Annual Review of Anthropology., 48: 45-60.

MUDDE, C. 2007. Populist Radical Right Parties in Europe. Cambridge:

Cambridge University Press.

MÜLLER, Jan-Werner. 2016. What is populism? Philadelphia: University of Pennsylvania.

NEGRI, C. 2021. "Radicalização da Direita e naturalização das Desigualdade". In:

R. Igreja, C. Negri (eds.), Desigualdades Globais e Justiça Social Interfaces Teóricas, Acesso à Justiça e

Democracia. Brasília FLACSO $369-393$

OHEMICHEN-BAZAN, Cristina. 2020. "El racismo anti-inmigrante en Estados Unidos y el giro global a la derecha”. In: A. Beaudoin Duquette et al. (eds.), Movilidades y fronteras: una mirada transdisciplinar. Ciudad de México: Universidad Nacional Autónoma de México, Instituto de Investigaciones Antropológicas. PASIEKA Agnieszka. 2019. "Anthropology of the far right What if we like the 'unlikeable' others?". Anthropology Today, 35(1):3-6.

POLI, Alexandra; ARUN, Onur. 2021. "Exploring the Connection Between Inequalities and Radicalisation: A Focus Through a Meta-Ethnographic Synthesis of Qualitative Studies”. In: R. Igreja, C. Negri (eds.), Desigualdades Globais e Justiça Social Interfaces Teóricas, Acesso à Justiça e Democracia. Brasília; FLACSO: $394-437$ 
POLI, Alexandra; ARUN, Onur. 2019 Report on the Meta-Ethnographic Synthesis of Qualitative Studies on Inequality and Youth Radicalisation - Dialogue About Radicalisation and Equality - DARE. Mimeo.

POWELL, Bingham G. 1986. "Extremist parties and political turmoil: two puzzles". Am.J. Polit. Sci., 30: $357-378$

RYDGREN, Jens. 2007. “The Sociology of the Radical Right”. Annu. Rev. Sociol, 33: 241-262.

SCHWARCZ, Lilia Moritz. 2019. Sobre o autoritarismo brasileiro. São Paulo:

Companhia das Letras.

SIEDER, Rachel. 2002. "Multiculturalism in latin America - indigenous rights, diversity and democracy". In: R. Sieder (ed.), Multiculturalism in latin America - indigenous rights, diversity and democracy. Londres: Palgrave. pp. 1-24.

SIERRA, María Teresa; IGREJA, Rebecca Lemos. 2020. "Neocolonialismo y justiciabilidad de los derechos indígenas. Introducción”. Cahiers des Amériques latines, 94(2). Available at $:$ https:/|journals.openedition. org/cal/11793

STOLLER, Paul. 2017. "More on the Anthropology of Trump". Anthropology Now, 9(1): 58-60

WIEVIORKA, M. (org.). 2017. Anti Racistes, Paris, Robert Laffont

WIEVIORKA, M. 2015. "Multiculturalisme: le débat est-il clos? " Hypotheses. Available at: https:/|wieviorka. hypotheses.org/3511

Rebecca Lemos Igreja

University of Brasilia

Department of Latin American Studies (ELA/ICS)

Graduate Program in Law at the Faculty of Law

https://orcid.org/0000-0002-9533-2985

Email: rebeccaigreja@unb.br 